\title{
STUDIES ON BACTERIAL CELL MULTIPLICATION : SYNCHRONOUS SEGMENTATION OF FILAMENTOUS CELLS OF LACTOBACILLUS DELBRUECKII
}

\author{
IWAO KUSAKA and KAKUO KITAHARA \\ Institute of Applied Microbiology, University of Tokyo \\ Received for Publication, August 10, 1962
}

In the previous works the authors reported on abnormal elongation of cells of Lactobacillus delbrueckii caused by the growth under deficiency of certain vitamins(1). Cytological and biochemical studies on filamentous cells produced under the influence of vitamin $B_{12}$ deficiency revealed that this abnormal growth is associated with some disorder in biosynthesis of deoxyribonucleic acid (DNA) and phospholipid(2), It was suggested that this metabolic disorder is responsible for the specific inhibition of cell division which led to the formation of filamentous cells $(3)$.

The earlier reports have also shown that the filamentous cells still retain the ability to divide into normal cells when they are supplied with a sufficient amount of a vitamin, the deficiency of which caused the elongation of cells. This observation suggested the possibility to find out a condition under which only the process of cell division can occur. The work reported in this paper established a defined nutritional condition under which segmentation of filamentous cells occurs synchronously without subsequent separation and growth of daughter cells.

\section{MATERIALS AND METHODS}

\section{Preparation of Filamentous Cells of Uniform Length}

The organism used in this study was Lactobacills delbrueckii No. 1 as in the previovs works. Normal cells of this organism were obtained by cultivation in the GYP medium which had the following composition: glucose, $2 \%$; yeast extract, $1 \%$; peptone, $1 \%$; anhydrous sodium acetate, $2 \%(\mathrm{pH} 6.8$ ). Filamentous cells are usually obtained by inoculating normal cells into the Vitamin $B_{12}$ Assay Medium (Difco) without addition of vitamin $B_{12}$. The filamentous cells thus obtained consisted, however, of elongated cells of various lengths and were inadequate for the present study with the reason described below. In order to prepare a population of filamentous cells of uniform length, the organism was precultured in the modified GYP medium, in which the content of glucose was reduced to $1 \%$. After 15 hours of incubation in this medium, cells were harvested and washed with $1 \% \mathrm{NaCl}$ solution. They were then inoculated into the Vitamin $B_{12}$ Assay Medium so as to give a cell density of $5 \times 10^{7}$ cells per ml. After 10 hours of cultiva- 
tion, 70 per cent of all cells were the filaments of $50-60 \mu$ in length.

Cultivation and incubation of the organism were always carried out at $45^{\circ}$.

\section{Cytological Methods}

The division of filamentous cells was followed microscopically. The onset of division was discerned by observing under a phase contrast microscope a constriction of cell wall at the points where a transverse septa were to be formed. The formation of septa was examined by staining the cells with Alcian blue method (4). Nuclear bodies were stained with $\mathrm{HCl}$-Giemsa (5).

\section{RESULTS AND DISCUSSION}

\section{Synchronization of Segmentation of Filamentous Cells}

As reported earlier, filamentous cells of $L$. delbrueckii produced by vitamin $B_{12}$ deficiency were able to divide into normal cells when supplied $1 \mu \mathrm{g}$ per $\mathrm{ml}$ of the said vitamin. During the process of restoration from abnormal state, the cells was also found to recover, at first, the Gram-positivity which was lost in the filamentous state. Subsequent segmentation of each filamentous cell into a chain separated by a number of transverse septa occurs simultaneously, followed by simultaneous separation of each member rod. It was also found that the time necessary for the resumption of the segmentation varied according to the extent of elongation of cells: the longer the filaments the later the initiation of segmentation (Fig. 1). Therefore, for the purpose of synchronizing the segmentation of filamentous cells, it was necessary to obtain a population of filamentous cells of uniform length; this was accomplished by the procedure described above. Filamentous cells of uniform length thus prepared were transfered into media of various com-

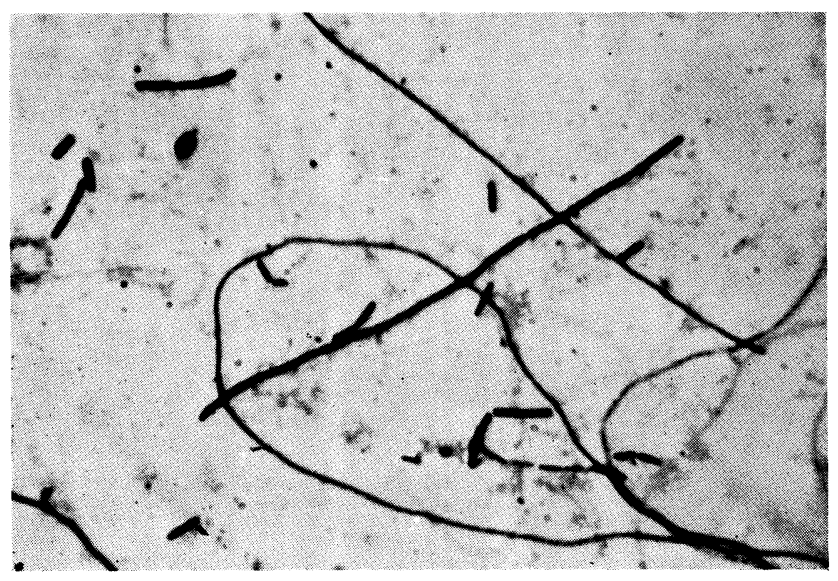

Fig. 1. Segmentation of filamentous cells. (Gram stain) 


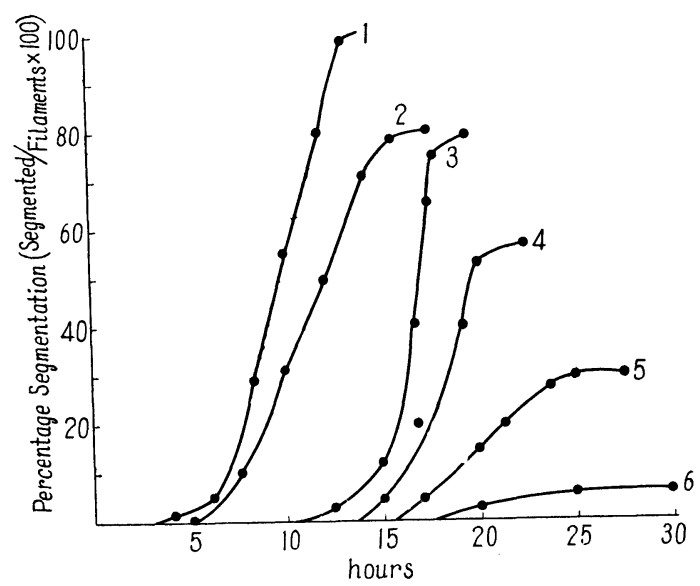

Fig. 2. Segmentation of filamentous cells under several nutritional conditions.

Numbers indicated in this figure represent kinds of media used for the segmentation of filamentous cells. Composition of these media are as follows:

\begin{tabular}{|c|c|c|c|c|c|c|}
\hline Ingredient & 1 & 2 & 3 & 4 & 5 & 6 \\
\hline $\mathrm{B}_{12}$ Assay Medium USP & + & & & & & \\
\hline basal medium & & + & + & + & + & + \\
\hline casamino acid, $5 \mathrm{mg} / \mathrm{ml}$ & & + & & & & \\
\hline casamino acid, $2 \mathrm{mg} / \mathrm{ml}$ & & & + & + & + & + \\
\hline glucose, $5 \mathrm{mg} / \mathrm{ml}$ & & + & + & + & + & \\
\hline adenine, $10 \mathrm{mg} / \mathrm{ml}$ & & + & + & + & + & + \\
\hline guanine, $10 \mu \mathrm{g} / \mathrm{ml}$ & & + & + & + & + & + \\
\hline uracil, $10 \mu \mathrm{g} / \mathrm{ml}$ & & + & + & + & + & + \\
\hline pantothenic acid, $10 \mu \mathrm{g} / \mathrm{ml}$ & & + & & & & \\
\hline pantothenic acid, $1 \mu \mathrm{g} / \mathrm{ml}$ & & & + & + & & \\
\hline $\mathrm{B}_{12}, 1 \mu \mathrm{g} / \mathrm{ml}$ & + & + & + & + & + & + \\
\hline riboflavin, $1 \mu \mathrm{g} / \mathrm{ml}$ & & + & + & + & + & + \\
\hline niacin, $1 \mu \mathrm{g} / \mathrm{ml}$ & & + & + & & & + \\
\hline folic acid, $0.1 \mu \mathrm{g} / \mathrm{ml}$ & & + & + & + & + & + \\
\hline
\end{tabular}


positions to find out a nutritional condition which causes resumption of synchronous divisions. In all experiments of this type, the inoculum size was adjusted to $5 \times 10^{7}$ filaments per $\mathrm{ml}$.

Preliminary experiments showed that energy and nitrogen sources as well as some inorganic ions, other than vitamin $B_{12}$, were indispensable for division. From these experiments a medium of the following composition was prepared: $0.01 \%$ each of tryptophane and cystine; $\mathrm{KH}_{2} \mathrm{PO}_{4}, 0.05 \% ; \mathrm{K}_{2} \mathrm{HPO}_{4}, 0.05 \%$; $\mathrm{MgSO}_{4}, 0.01 \% ; \mathrm{MnSO}_{4}, 0.001 \% ; \mathrm{FeSO}_{4}, 0.001 \% ; \mathrm{pH} 6.8$. To this basal medium were added glucose, vitamin-free-casamino acid (Difco), purine and pyrimidine bases as well as vitamins required by this organism in various combinations and their effects on segmentation of filamentous cells were observed microscopically. Fig. 2 illustrates the results obtained under some of the conditions tested. When the filamentous cells were transfered into the Vitamin $B_{12}$ Assay Medium supplementd with vitamin $B_{12}$, segmentation occurred after five hours and each filament divided into a number of short rods of nearly the same size as that of normal cells (curve 1). On further incubation of these rods, they followed normal cycles of growth and division. The course of events was entirely different when the filaments were inoculated into the basal medium supplemented with adenine, guanine, uracil, and five vitamins (vitamin $B_{12}$, vitamin $B_{2}$, niacin, folic acid, and pantothenic acid) essential for the growth of this organism. Although segmentation was initiated even after 12 hours, it proceeded quite synchronously; about 70 per cent of the filaments segmented within 2.5 hours as shown by curve 3 (see also Fig. 3). In this case the chains of daughter cells thus formed did not separate from each other differing from the case of curve 1 . When one or more of the nutrients were eliminated from the medium, initiation of segmentation occurred much later with less synchrony (curves 4 and 5). The

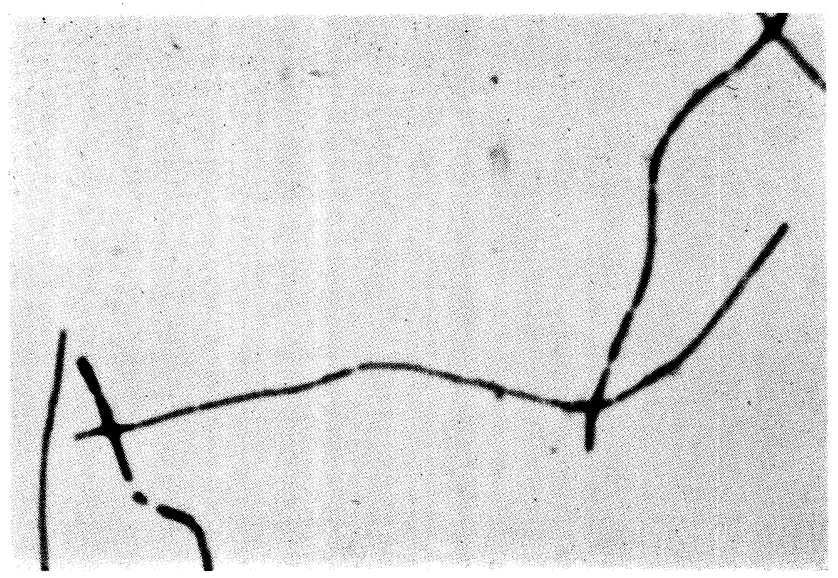

Fig. 3. Segmentation of filamentous cells in

"segmentation medium"

(phase contrast photomicrograph) 
fact that energy source is essential for the process of segmentation is clearly shown by curve 6 . It should also be added that when the concentration of casamino acid and pantothenic acid was raised several times, the result was similar to that shown by curve 1 (curve 2 ).

From these experiments, it was revealed that the medium employed in the case of curve 3 can support synchronous segmentation of filamentous cells without subsequent separation and growth of daughter cells. Thus this medium may be called "segmentation medium". The uniformity of filamentous cells is yet incomplete in the present study. This suggests the possibility of improving the extent of synchrony of segmentation, if a popuiation of more uniform cell length would be obtained.

\section{Behavior of Nucelar Bodies during the Course of Segmentation}

Earlier reports have shown that nuclear bodies of filamentous cells are stained with Giemsa only faintly and are arrayed irregularly in the filaments. The average distance between nuclear bodies was estimated to be twice as long as that in normal cells. It was further confirmed that the filamentous cells were characterized by lower DNA content than that of normal cells.

Employing the technique of synchronizing segmentation of filamentous cells, the course of change in nuclear bodies during the course of segmentation was followed. Filamentous cells were allowed to divide synchronously in the "segmentation medium", then samples were withdrawn at intervals, and stained with Giemsa to examine cytological changes in nuclear bodies. During the first 8 hours of incubation, nuclear bodies retained intracellular arrangement and staining property characteristic of filamentous cells (Fig. 4). Between the 8 th and 12th hour of incubation, the nuclear bodies became larger and more intensely stainable, suggesting the onset of DNA synthesis (Fig. 5). After 12 hours the appearance of nuclear bodies were nearly the same as those of normal cells and they were arrayed at rather regular intervals along the long axis of filamentous cell (Fig. 6). The formation of

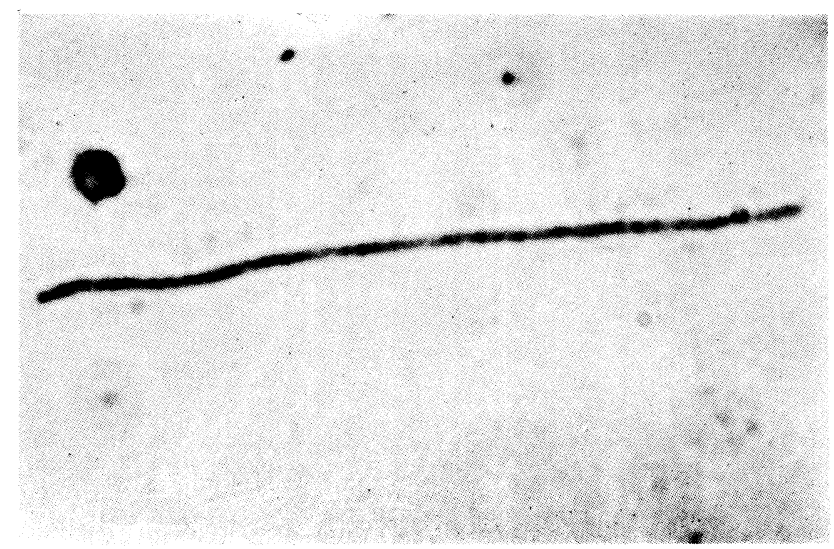

Fig. 4. Nuclear bodies in filamentous cells after 8 hours of incubation in "segmentation medium". 


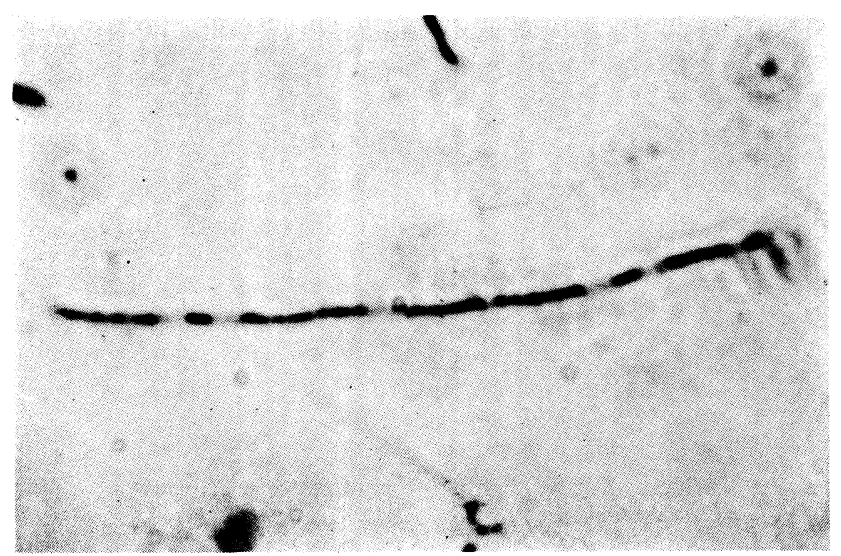

Fig. 5. Nuclear bodies in filamentous cells between 8th and 12th hour of incubation in "segmentation medium".

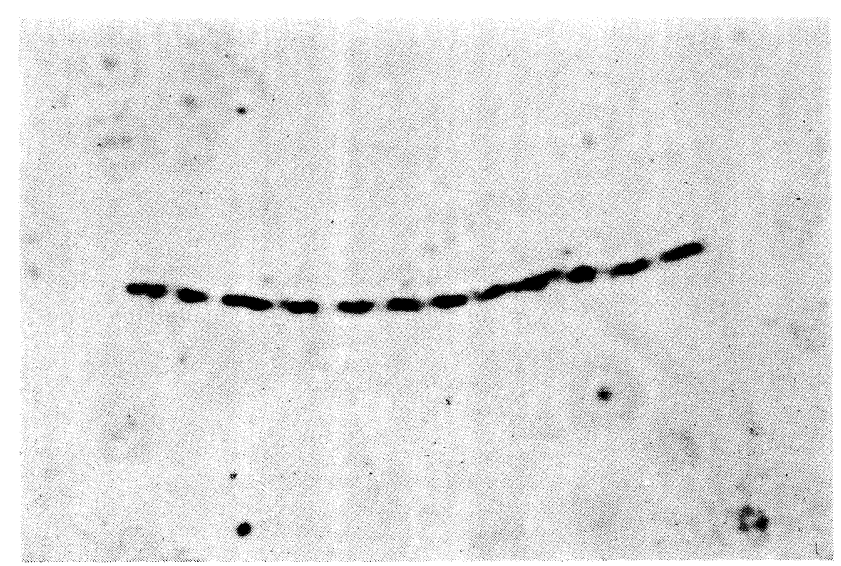

Fig. 6. Nuclear bodies in filamentous cells after 12 hours of incubation in "segmentation medium".

transverse septa commenced also at this time as shown by curve 3 of Fig. 2. These observations show that synthesis and rearrangement of nuclear materials take place before segmentation occurs. Thus it appears that recovery of nuclear bodies into normal state is necessary for the initiation of segmentation of filamentous cells.

\section{SUMMARY}

Several nutritional conditions were tested for their capacity to synchronize the segmentation of filamentous cells of Lactobacillus delbrueckii produced by growth under vitamin $B_{12}$ deficiency. A medium containing adenine, 
guanine, uracil, vitamin $\mathrm{B}_{2}, \mathrm{~B}_{12}$, folic acid, niacin, and pantothenic acid, beside glucose, amino acid, and inorganic salts was found to be most effective in synchronizing the segmentation of filamentous cells which was not followed by separation and growth of daughter cells. Cytological observations disclosed that the segmentation of filamentous cells in this medium was preceded by an increase in stainability with $\mathrm{HCl}$-Giemsa and the rearrangement in cells of nuclear bodies.

\section{REFERENCES}

(1) K. Kitahara and I. Kusaka: J. Gen. Appl. Microbiol. 5, 78 (1959).

(2) I. Kusaka and K. Kitahara: Agr. Biol. Chem. 25, 807 (1961).

(3) M. Weвв: "Biochemistry of Morphogenesis" Edited by W. J. Nickerson, Pergamon Press (1959) P. 71.

(4) J. TOMcsiK and J. B. Grace: J. Gen. Microbiol. 13, 105 (1955).

(5) C. F. Robinow: Can. J. Microbiol. 3, 771 (1957). 